\title{
Assessment of Autologous Procedures under Conditions of the Current G-DRG System
}

\author{
Alexander Schleppers \\ Klinik für Anästhesiologie und Operative Intensivmedizin, Universitätsklinikum Mannheim, Germany
}

\author{
Key Words \\ Diagnosis Related Groups · DRGs · OPS 2006 · Coding · \\ Process costs
}

\section{Summary}

Autologous hemotherapy does not have any relevance in the current reimbursement system but can be reflected by coding in the OPS catalogue 2006 within the G-DRG (German Refined Diagnosis Related Group) system. Code quality of these procedures can certainly be improved in order to ameliorate the basis of calculation within the DRGs. Autologous procedures play an important role within the perioperative DRG process with respect to quality improvement and cost reduction. Calculation algorithms which are generally valid should be established to precisely evaluate previous findings.

\section{DRG Reimbursement System}

DRGs (Diagnosis Related Groups) are case groups homogenous in costs and defined by diagnosis and procedures. The degree of medical homogeneity depends on the system. One case is usually allocated to a case group with a special compensation. As the system of a classification algorithm cannot be influenced in a single case, certain treatments might not be reimbursed adequately.

Data basis for DRG categorization is the encoding of diagnoses according to ICD $10 \mathrm{GM}$ and of the procedures according to OPS referring to the currently valid version. In combination with some additional data like age, sex, artificial respi-

\author{
Schlüsselwörter \\ Diagnosis Related Groups · DRGs · OPS 2006 • \\ Kodierung · Prozesskosten
}

\section{Zusammenfassung}

Autologe Hämotherapieverfahren sind derzeit, wenn auch nicht vergütungsrelevant, über die Kodierung nach OPS 2006 im G-DRG(German Refined Diagnosis Related Group)-System abbildbar. Die Kodierungsqualität dieser Verfahren vor Ort ist jedoch noch verbesserungsfähig, um die Kalkulationsgrundlage in den DRGs zu verbessern. Weit höher ist jedoch die Bedeutung autologer Verfahren als Beitrag zur Qualitätsverbesserung und Kostenreduktion im perioperativen DRG-Prozess einzuschätzen. Die Etablierung allgemein gültiger Kalkulationsalgorithmen ist jedoch zur genaueren Validierung der bislang vorliegenden Studienergebnisse erforderlich.

ration time, intensive scoring (SAPS II and TISS core 10), reimbursement is determined. In contrast to reimbursement according to hospital and nursing charges, case-based lump sums and special rewards, the length of stay, and the ward where the patient is accommodated are no relevant factors.

\section{Data Basis}

214 hospitals are included in the calculation of the case-based lump sum catalogue valid in 2006. Compared to 2005, 66 additional hospitals provided their data for the calculation. The increased number might be due to a partial refinancing of the

\begin{tabular}{ll}
\hline KARGER & @ 2006 S. Karger GmbH, Freiburg \\
Fax +497614520714 & Accessible online at: \\
$\begin{array}{l}\text { E-mail Information@Karger.de } \\
\text { www.karger.com }\end{array}$ & www.karger.com/tmh
\end{tabular}


Table 1. Mapping of autologous blood donation (OPS 8-803.0) in certain DRGs in percent

\begin{tabular}{|c|c|c|}
\hline Description & DRG & $\%$ \\
\hline Ambilateral implantation of an hip or knee endoprosthesis & $\mathrm{I} 36 \mathrm{Z}$ & 16.91 \\
\hline $\begin{array}{l}\text { Revision or replacement of the hip joint without complicating diagnosis, } \\
\text { arthrodesis, complex surgery and very severe clinical course }\end{array}$ & I $48 \mathrm{Z}$ & 13.41 \\
\hline $\begin{array}{l}\text { Implantation of a bicondylar endoprosthesis or other implantation/revision } \\
\text { of an endoprosthesis at the knee }\end{array}$ & I $44 \mathrm{~A}$ & 9.41 \\
\hline Replacement of hip endoprosthesis & I46Z & 7.66 \\
\hline $\begin{array}{l}\text { Replacement or implantation of an hinge endoprosthesis or a special } \\
\text { prosthesis at the knee }\end{array}$ & I $43 Z$ & 5.16 \\
\hline $\begin{array}{l}\text { Revision or replacement of the hip joint with complicating diagnosis, } \\
\text { arthrodesis, ambilateral surgery or repeated major surgery at joints of the } \\
\text { lower extremities with complex intervention }\end{array}$ & $\mathrm{I} 03 \mathrm{Z}$ & 4.88 \\
\hline Several interventions at endoprostheses of the knee joint & I44B & 3.06 \\
\hline $\begin{array}{l}\text { Other major joint replacement or revision/replacement of the hip joint } \\
\text { without complicating diagnosis, arthrodesis, complex surgery and } \\
\text { very severe clinical course }\end{array}$ & $\mathrm{I} 05 \mathrm{Z}$ & 2.76 \\
\hline $\begin{array}{l}\text { Revision or replacement of the hip joint without complicating diagnosis, } \\
\text { arthrodesis, complex surgery and very severe clinical course }\end{array}$ & I47Z & 1.48 \\
\hline
\end{tabular}

costs as regards the calculation. Interestingly, only 133 out of the total of 214 participating hospitals were also included in the calculation for the catalogue in the year 2005. Thus, 81 hospitals contributed to create 'newly mixed data'. 9 of the clinics included in the calculation were university clinics.

Around 3.5 million data were supplied which increases the total of delivered data concerning reimbursement per case by approximately 600,000. About 2.6 million data could be used for the calculation after having been proved for plausibility in Institut für das Entgeltsystem im Krankenhaus (InEK). The relatively high number of data which were not plausible is based on inferior quality of the data rather than on a more detailed examination of plausibility by the InEK.

\section{Coding within DRG System / DRG Ratios}

The 2006 version of the G-DRG (German Refined Diagnosis Related Group) system includes 954 DRGs in total (76 additional DRGs compared to the 2005 version). Out of these, 912 are included in the case-based lump sum catalogue, and 40 of the 954 DRGs are included in the catalogue of reimbursement cases which do not belong to the case-based lump sum catalogue.

The case-based lump sum catalogue 2006 reveals 17 explicit one-day hospitalization DRGs (19 in the year before). In contrast to the decrease of explicit one-day hospitalization DRGs, 25 further implicit one-day hospitalization DRGs are included in the case-based lump sum catalogue 2006 which now covers a total of 241 implicit one-day hospitalization DRGs.

Compared to the previous year, the extent of additional reimbursements increased slightly. Appendix 2 (catalogue of additional reimbursements) displays 40 evaluated additional reimbursements (previous year 35). Appendix 4 (additional reim- bursements according to $\S 6$, paragraph 1 Krankenhausentgeltgesetz (KHEntgG)) includes 42 additional reimbursement cases based on individual agreements of different hospitals (previous year 36).

\section{Coding of Autologous Procedures}

Code no. 8-803 (collection and transfusion of blood) in the OPS catalogue 2006 describes the different autologous procedures which can be documented in 2006:

8-803.0 Autologous donation of blood, including re-transfusion,

8-803.1 normovolemic hemodilution referring to surgery,

8-803.2 autotransfusion using a Cell Saver without radiotherapy,

8-803.3 autotransfusion using a Cell Saver with radiotherapy. Note: A code of this group can only be employed once per hospital stay.

\section{Depiction of Autologous Procedures in the G-DRGs}

By analyzing the depiction of autologous procedures in the GDRG system on the basis of the DRG Report Browser for the year 2006, it can be shown that autologous procedures were only partially documented in the calculation hospitals. This might be explained by the fact that the documentation of these procedures does not result in a higher classification within the DRG groups and was therefore neglected. Tables 1 and 2 show the DRGs for the autologous donation of blood and the autotransfusion using a Cell Saver and the percentage of patients for which the autologous procedures were documented. 
Table 2. Mapping of the Cell Saver (OPS 8-803.2) in certain DRGs in percent

\begin{tabular}{|c|c|c|}
\hline Description & DRG & $\%$ \\
\hline Lung transplantation with artificial respiration $>47 \mathrm{~h}$ and $<180 \mathrm{~h}$ & A03B & 40.00 \\
\hline $\begin{array}{l}\text { Complex vertebral body fusion with very severe clinical course or complex } \\
\text { surgical intervention at the spinal column }\end{array}$ & I06Z & 34.88 \\
\hline Ambilateral implantation of hip or knee endoprostheses & $\mathrm{I} 36 \mathrm{Z}$ & 31.62 \\
\hline Replacement of hip endoprosthesis & I46Z & 26.46 \\
\hline Heart transplantation with artificial respiration $>179 \mathrm{~h}$ & $\mathrm{~A} 05 \mathrm{~A}$ & 26.32 \\
\hline Complex vertebral body fusion without very severe clinical course & I19Z & 19.67 \\
\hline Complex vertebral body fusion with very severe clinical course & I09A & 16.50 \\
\hline $\begin{array}{l}\text { Implantation of a bicondylar endoprosthesis or other implantation/revision } \\
\text { of an endoprosthesis at the knee }\end{array}$ & I44A & 16.12 \\
\hline $\begin{array}{l}\text { Revision or replacement of the hip joint without complicating diagnosis, } \\
\text { arthrodesis, complex surgery and very severe clinical course }\end{array}$ & I $48 \mathrm{Z}$ & 15.93 \\
\hline $\begin{array}{l}\text { Replacement or implantation of an hinge endoprosthesis or a special } \\
\text { prosthesis at the knee }\end{array}$ & I43Z & 13.96 \\
\hline $\begin{array}{l}\text { Major reconstructive vascular interventions without heart lung machine, } \\
\text { but with complicating procedures and thoracoabdominal aneurysma }\end{array}$ & F08Z & 13.78 \\
\hline $\begin{array}{l}\text { Ambilateral surgery or repeated major surgery at joints of the lower } \\
\text { extremities with complex diagnosis }\end{array}$ & $\mathrm{I} 01 \mathrm{Z}$ & 13.07 \\
\hline $\begin{array}{l}\text { Revision or replacement of the hip joint with complicating diagnosis, } \\
\text { arthrodesis, ambilateral surgery or repeated major surgery at joints of the } \\
\text { lower extremities with complex intervention }\end{array}$ & $\mathrm{I} 03 \mathrm{Z}$ & 12.84 \\
\hline $\begin{array}{l}\text { Other interventions at the hip joint or femur with repeated intervention, } \\
\text { complex procedure or diagnosis, and very severe clinical course }\end{array}$ & I08A & 8.29 \\
\hline $\begin{array}{l}\text { Other major joint replacement or revision/replacement of the hip joint } \\
\text { without complicating diagnosis, arthrodesis, complex surgery and very } \\
\text { severe clinical course }\end{array}$ & $\mathrm{I} 05 \mathrm{Z}$ & 8.19 \\
\hline Various endoprosthetic interventions at the knee joint & I44B & 3.34 \\
\hline $\begin{array}{l}\text { Revision or replacement of the hip joint without complicating diagnosis, } \\
\text { arthrodesis, complex surgery and very severe clinical course }\end{array}$ & $\mathrm{I} 47 \mathrm{Z}$ & 2.51 \\
\hline
\end{tabular}

Creating a logical row from the depiction of autologous procedures to the coding of the procedures on the basis of OPS catalogue 2006 to further topics such as quality and economy, additional connections between DRGs and autologous procedures become obvious.

\section{Quality Report}

According to $§ 137 \mathrm{ff}$ SGB V, German hospitals are obliged to submit a quality report every 2 years containing the following parts:

- basic part (data referring to structure and performance),

- performance referring to special fields,

- quality assurance (BQS (Bundesgeschäftsstelle Qualitätssicherung $\mathrm{gGmbH}$ ) procedures, minimum amount), quality policy, quality management.

Quality reports are published via internet, thus being available for all patients and doctors in private practice. This may support/facilitate the choice of the appropriate hospital on the basis of the presented results. In the part with individual texts (quality policy and quality management), the autologous procedures (saving foreign blood) can be presented in detail, and these parts may also be used as marketing instruments.

\section{Minimum Regulation}

Table 3 displays an overview over the development of minimum regulations in the years 2005-2006. There is a striking increase in performance figures in the year 2006 for the case 'knee TEP' (TEP = total endoprosthesis) accompanying the introduction of a minimum amount for this case. According to the report of Gerdelmann (VDAK) during the DRG forum 2005 in Berlin, approximately 950 hospitals provided 'knee TEP' in the year 2004 - but $52 \%$ of these hospitals less than 50 times and $25 \%$ less than 25 times. In 2006, more than 500 of these hospitals cannot provide the knee TEP operation anymore due to the minimum regulations - apart from a few exceptions referring to temporary regulations. Predominantly, this is due to regulations regarding the appropriate operating unit, but clinical departments such as anesthesiology, pain therapy and post anesthesia care unit (PACU) are also involved. Changing capabilities within operative procedures on the basis of minimum regulations also include the associated autologous procedures. If the number of operations decreases, also the referring performance of autologous procedures, e.g. the use of Cell Saver or autologous donation of blood, are impaired. In this case, cost calculations and economic evaluations have to be adjusted accordingly. 
Table 3. Development of the minimum regulations (Mindestmengenregelungen) 2005-2006

\begin{tabular}{llcl}
\hline Intervention & $2005^{\mathrm{a}}$ & $2005^{\mathrm{b}}$ & 2006 \\
\hline Liver transplantation & 10 & & 20 \\
Kidney transplantation & 20 & & 25 \\
Knee TEP & 5 & 5 & 50 \\
Complex esophageal interventions & 5 & 5 & 10 \\
Complex pancreatic interventions & $5 \pm 2$ & & 25 \\
Stem cell transplantation & $12 \pm$ & \\
\end{tabular}

aPer hospital.

${ }^{b}$ Per physician

\section{Procedure Costs}

The cost matrix in the DRG Report Browser 2006 presents an overview over the total costs of each DRG with subgroups according to the aggregated cost centers and type of costs. These data constitute a significant benchmarking data pool for evaluation of procedure costs on the basis of the DRGs.

A detailed analysis of costs and procedures allows a comparative evaluation of various medical therapeutic procedures. It is the task of hospital controlling to identify inefficient treatment lines and to show possible solutions to optimize procedures. Based on these data, each specialized unit/institute has to re-structure treatment procedures and increase cost efficiency. From the perspective of treatment quality, the head of each specialized unit has the responsibility to advance the internal development of treatment lines which support a decrease in length of hospital stay without a loss of quality. Generally, the economic as well as the medical responsibility will continue to shift towards the specialized units. Apart from medical expertise, this change will require an increasing economic knowledge of the heads of the different departments. These facts are also relevant for the 'blood' topic which is dis- cussed quite controversially in the current literature. Where is the application of foreign blood including all referring costs (collection, distribution, infection rate, allergic reactions, etc.) still indicated? When is the use of autologous procedures such as autologous donation of blood or autotransfusion using a Cell Saver profitable?

Previous studies reveal that the donation of foreign blood can imply a higher risk for inpatients with hip or knee TEP to suffer from complications during hospital stay [1]. As this results in an increased length of hospital stay and increased procedure costs, it is obvious that such a situation is extremely disadvantageous in the age of the DRG system. From this point of view it is clear that in planned operations the use of foreign blood without previous attempts to use autologous procedures is obsolete.

The findings concerning the comparative evaluation of autologous procedures are much more heterogeneous. Glenngard et al. [2] showed in a comparative cost study - in consideration of opportunity costs such as infection rates, etc. - clear differences in costs. However, these cost studies may not be reproducible in a single case in another hospital, as cost structures differ/vary considerably in different countries, and production costs - especially for donation of autologous blood - depend strongly on organization structure, capacity and rejection.

Calculation algorithms which are generally valid and include/consider all opportunity costs should necessarily be established to precisely evaluate the use of autologous procedures on the basis of a DRG cost matrix.

\section{References}

1 Claus A, Asche G, Brade J, Bosing-Schwenkglenks M, Horchler H, Muller-Farber J, Schumm W, Weise K, Scharf HP: Identifizierung von Risikofaktoren postoperativer Komplikationen in der primären Knieendoprothetik. Unfallchirurg 2006;109:5-12.

2 Glenngard AH, Persson U, Soderman C: Costs associated with blood transfusions in Sweden - the societal cost of autologous, allogeneic and perioperative RBC transfusion. Transfus Med. 2005;15:295-306. 